\title{
Theories and models of globalization ethicizing
}

\author{
Dritan Abazović ${ }^{1}$
}

\begin{abstract}
Globalization as a phenomenon is under the magnifying glass of many philosophical discussions and theoretical deliberations. While most theorists deal with issues that are predominantly of economic or political character, this article has a different logic. The article presents six theories which in their own way explain the need for movement by ethicizing globalization. Globalization is a process that affects all and as such it has become inevitable, but it is up the people to determine its course and make it either functional or uncontrolled. The survival and development of any society is measured primarily by the quality of its moral and ethical foundation. Therefore, it is clear that global society can survive and be functional only if it finds a minimum consensus on ethical norms or, as said in theory, if it establishes its ethical system based on which it would be built and developed.
\end{abstract}

Keywords: Ethicizing Globalization; Social Utilitarianism; Ethics of Communicative Discourse; Ethics Based on Human Nature; Ethics in Religious Traditions of Human Kind; Ethics of The Poor; Personalistic Ethics.

\section{INTRODUCTION}

In the process of globalized information, communication, politics, economics, cultures, numerous issues and social deviation are emerged. It is not something that was not expected, primarily because each phenomenon also has negative effects. The problem is that those effects are thought about relatively late, when the consequences are so great that it is more difficult to control them. It is the same case with global responsibility, which should be occur in response to the challenges that globalization has set before us. Globalization as a process is not just a fashionable slogan for the times we live in; it is indeed a symbol of our time and of our era. If we accept that it occurs as a known fact, as a symbol, then it can be viewed from several aspects. And while some argue that it is a "globalization of the economy," we can optimistically say that it is a "globalization of ethics". So on one hand, it is talked about a completely wrong road of neo-colonization and uniformity, but on the other hand voices are heard that this is a process which for the first time in the history of mankind is creating a prerequisite for an integrated world without conflict. A concept of globalization with a human face or human globalization is wanted. A famous theologian, professor at the University of Barcelona, José Ignacio González Faus believes that the current globalization actually negates the concept of universal humanity, because it is too devoted to the material side of life. Faus goes even further in the radicalization of his criticism, and says: "that globalization was just an excuse for money flow" and that "other flows are still limited by a variety of barriers" (Faus, 2001:620). This makes us again to ask the same question that we have asked so many times, which refers to what is a man as a person, an individual and a citizen? What does he represent in this world? "Globalization, a priori, is neither good nor bad. It will be what people make of it. No system is an end in itself, and it is necessary to insist that globalization, like any other

1 M.A., Ph.D. Student at the University of Montenegro, Montenegro, Ulcinj, +382 69545822 , katakomba@hotmail.com 
system, must be at the service of the human person; it must serve solidarity and the common good." (Faus, 2001: 621). So, this means that only people are accountable, because only they can know the truth, and truth is of great importance for the process of globalization. When we mentioned that problems are globalized, we need to admit that models, ways and opinions on their overcoming are also globalized. The process we are talking about, offers universalization of society in general, but that does not mean that we need such an universalization. When we talk about global ethics, universal ethics is consciously avoided, because such thinking is contrary to the nature of diversified world. The story of universalization does not cease to be linked to globalization, but such universalities do not exist; on the contrary, we could say it is a case of disintegration of the world rather than integration precisely because of the differences that exist in modern society. Of course, many would say that difference is a natural category too, that each process has its "winners" and "losers", and we will admit that this argument is valid as well. The question of winners and losers is important for this topic, because it raises the question whether it is possible to develop the "ethos of globalization" or "to globalize certain ethics"? In doing so, as we mentioned, the establishment of a certain system of values that would be minimally accepted by all parties is distinguished, of course. We underlined that the establishment of such a system is really complicated and very complex due to the many obstacles which prevent it. Hardly anyone is able to offer a specific model that would be final, but when we have already mentioned the globalization of thought, then we can confidently name several contemporary models of ethics, and which in any case can be useful in thinking about responsible global policy based on a new ethical system.

\section{MODELS OF GLOBALIZITION ETICIZING}

Leonardo Boff, in his book "Ethics for a New World" (org. Ethik für eine neue Welt) introduces a few models that apply to the ethics of globalization. These are above all: social utilitarianism, ethics of communicative discourse, ethics based on human nature, ethics in religious traditions of humankind, ethics of the poor, and personalistic ethics. Each of these models offers a foundation of global ethics, but of course on different grounds. When it comes to a dominant model of utilitarian ethics today, the model that privileges neoliberal concept of globalization, it is mainly thought of its practical applicability. On the other hand, this ethics always measures actions based on their performances, and it is very difficult to make arguments if we begin from the human factor, that we are dedicated to. Efficiency often wants to justify everything. Boff criticizes the fact that efficiency is always at the expense of "relations", thereby marginalizing the interpersonal dimension. His concerns are also related to the fact that, as he says, "current discriminatory order is sacralised" (Boff, 2000:49). That is why it is often said that utilitarianism is "the ethics of the satiated". Elmar Waibl points to the so-called "bridge model", which assumes that deliberate action is one that stems from economic reasons. It is a viewpoint that connects morality with the capital, and it is a situation where the consequences are observed on the basis of earnings. "We cannot rely on morality, which is seen as investment capital, because just like Rousseau said a long time ago, "one who only does good for the money, is waiting only to be better paid to do bad"(Ibid,: 57). It is difficult to agree with this model because the goal of any ethics, or at least one that is close to us and that we are looking, is to be in the service of the human in any system, and not to be a justification and validation of different systems. Therefore, it is difficult to accept the model of social utilitarianism, but it must be mentioned because it is very relevant in considering the perspective of globalization, no matter what the strength and force of its argument. Boff is considering another model, the "etbics of communicative discourse". This model indeed testifies to the constructive effort to find a way to create a consensus among the various stakeholders. Its characteristic is to stand at a point that spreads a message of aspiration for global dialogue between peoples, nations, and individuals of north, south, regions, philosophies, religions, institutions, etc. This model is mostly connected to Jurgen Habermas, and his outline exists, but it is of a rather abstract nature. The problem that arises in this model is that it, in principle propagates the material 
side of a man, ignoring the spiritual. In such a way, consensus is sought primarily for what is the problem of the poor, the hungry, the problem of the unemployed and so on. Food, clothing and housing are important, but man is still a dualistic being, that carries both materialism and spirituality in his nature. Aside from those material things, man also has a feeling of transcendence and the need for beauty, which is, of course, another argument that Boff actualizes. Ethics of communicative discourse invests its whole confidence in the human mind, and this model mainly promotes this as rationalism. We have repeatedly mentioned Rawls and his concept of the "overlapping consensus", which also included his foundations in classical rationalism. However, Boff rightly says that rationalism is not as effective when it comes to the "pathos", which is the only one that can promote solidarity and sympathy, because one society, no matter how much importance has been given to the dialogue, cannot open the horizon of hope and confidence to the humanity. We accept this argument, for the simple reason of knowing that morality is not merely recognition of the other, but also a feel and an idea of the other. What the world needs is a concept of "intermorality" as a global process of intercultural communication without coercion and consensus. Very often diversity is a problem as well, as much as it is okay to perceive it as wealth, because any diversity for diversity, which has no goal other than itself, is not a solution. The next model that is worth mentioning is the "ethics based on buman nature". This model is based on the ethics of anthropological constants. Constants, which can also include the will and the freedom, lead to having binding and universal norms. In the modern world, we need to admit, the biggest issue of ethics is objectivity. There are constant excuses that there are no generally valid or generally accepted ethical norms, which entail that all means to reach the goal are allowed. This entails other dilemmas too, as to what are the primary goals, which are the most important values, what priorities should a man have as his goal?! Ethics based on human nature begins with the fact that all people have the same human nature. This gives objectivity to the arguments, it poses the question on the truth of things, not just on the consensus of things. This enables us to have an intellectual discourse that everyone can understand. For example, we all have being human. Of course, we all have our own identity and our own peculiarities, which include different cultures and other differences. The ethical argument that adverts to the human nature or requirements of the human nature suggests that we should take into account what suits the objective conditions of human nature. Human nature, for example, knows no exclusion. If today's system "excludes" close to two thirds of humanity, then such a system is unacceptable for our nature, and should therefore be changed. The only issue that arises here is the possibility of thinking that stems from the negative human nature, which is also an integral part of our nature; but ethics is primarily oriented to the good, which is why one should stay on that road. The next model that we want to actualize refers to "ethics based on great religious traditions". This model of ethics was repeatedly affirmed by theologian Hans Kung. This model is primarily based on two benchmarks: the concrete truth and essential righteousness. Regardless of all philosophical theories that deal with the issue of truth, concrete truth means nothing else but a stop to all lies and deception, and righteousness means a stop to doing harm. If this is formalized and put in a certain form, then we can conclude that minimal consensus is summarized in the right to life, inviolable respect for the innocent and the pure, fair treatment of prisoners, and physical and mental integrity of the man. This is a minimum, and in absence of such minimum, it is not possible to establish a common life anywhere in the world. In particular, this means that the peoples found in their religions a mean that would achieve and guarantee a universal, unconditional character of minimal consensus. This is the "golden rule", one of the specific principles of the "Decalogue" which are common to all religions. As is usual, there are much criticisms relating to the ethics based on great religious traditions. Konrad Raiser asks: "Is it possible to live such an ethos without attachment to particular ethical and religious traditions? Is such ethos normative or it may be only regulative, i.e. focusing on a process of mutual respect and understanding? "(Raiser, 2001: 407). Further criticism concerning such model of ethics is that it is relatively abstract and that it is rather declarative than feasible and descriptive. Also the argument which says that the sacrifice of beliefs and principles for 
a consensus only causes increased intolerance and fundamentalism - is correct. Each argument is welcome and it just shows that responsible globalization needs to consider various options and modalities in order to reach the most appropriate solutions. Therefore, we continue and commit ourselves to another model of ethics, the one we could call "ethics of the poor and the oppressed". In order to clarify this concept, Boff cites Argentine philosopher and theologian Enrique Dussel. Asked how to reach universality (thinking of the ethics), Dussel ingeniously responds that "...it is reached only when we begin from the partial, meaning from those in last place, those whose survival is in doubt." So his whole concept is based on the poor, but he does not only target the poor, but the concept is general and applies to all. If we begin from the poor, it means beginning from the larger part and this imposes urgency as the first association. Any model that marginalizes the poor, remains selective and partial, so logically, it cannot be universalistic.

"Ethics needs to begin from the other, but not just another, but quite the other, which means from the poor and the oppressed. The poor, as such, is more than an economic category, it is the anthropological greatness. The poor has a face. Its face makes us recognize it as irreplaceable, provoking being calling for help" (Boff, 2000: 77). Ethics, in this sense, is the ethics of justice, understood in a way that the vast majority of people are given recognition and that those who feel excluded from society, are again introduced into the society. Here you can already see difficulties of ethics that should be based on a consensus. What does this minimum mean? The principles of justice are always maximalist. The right to recognition cannot be a matter of consensus, but rather its precondition. According to Boff, value and criterion of truth and universality of ethics are measured by the way we treat the poor and the oppressed. He uses this to derive the basic imperatives for the concept of global ethics, such as solidarity, responsibility, dialogue and the most important - attention. "Attention is the ratio of care in which a man discovers the world as a value. The world is not primarily a matter of human ownership and an arena of utilitarian interests. The world has its own intrinsic value and its own autonomy" (Ibid,:98). Considering all these ethical theories which arise as potential models for future global ethics and a system of values built at the global level, we understand the complexity of the issue, but we understand something else too that none of them is without a counter-argument, or simply said, without deficiencies. Each of them has true quality, but it also has a missing dimension. Today, in the modern world, debate refers not only to the issues of last theoretical foundation of morality, but it reached a phase where it refers to a fundamental self-understanding of people in general and to the sense of human practice. Globalization as a process is largely ambivalent and paradoxical, which is why the ethics that appears around it, also has quite vague solutions. The paradoxes of globalization are reflected in its universality, as well as in its excessive individualization. Such paradox is later reflected in the complete ethical system and moral activities of individuals or groups. Dialectics of homogeneity and heterogeneity, as such, in the process of globalization, but also in the process of global politics, is gaining great importance. Francis Schussler Fioranza explains these trends in the following way: "In today's globalization, ethical beliefs have particularistic and universalistic tendencies that emphasize particularity when it is needed so, or universality on another occasion. Ethical responds to the challenges of globalization are paradoxical in the same way. Some advocate particularism and pluralism, while others stimulate demand for universal ethics. Globalization simply imposes models and visions that a universal ethos cannot cope with, nor can a locally bounded particular ethos, nor moral particularism, nor universal ethics" (Fioranza, 2001: 456). Establishing a consensus seems really complicated when the value system of a society is in question. However, this should not be an argument to give up this quest, because the present imposes the need to find a code that would represent a minimum consent in some way. It is simply utopian to think that a universal system could be established that would have equal values, rule of a social or an economic order, which would be exactly the same in its ethical judgment of all situations. But this does not mean that the 
prospects of global ethos should not be explored. Such an assertion imposes the question where the standards of common ethical code should be looked for.

In a sea of diversity and particularity, it is really difficult to answer this question. "Instead of creating a minimal consensus, it is better to start with what we all have in common, and being a person is what we all have in common" (Tićac, 2009: 115). This starting point is quite correct and logical, therefore, we should start from the man and not allow globalization to continue to be irresponsible, and to relativize all values, to continue to homogenize lifestyles and cultures. This is reason enough to try to explain another model of ethics which could be global, and which is known in the social theory as the "personalistic ethics". If we are aware that globalization is aimed at expanding the borders, it should not be a priori accepted as inherently good, but ambivalent. The moral value of globalization, as well as of every other social process, depends on the value that such a process wants to produce. Whenever a society wants to re- socialize, even a global society, we can say that this at least causes controversy and disagreement. This does not mean that resocialization is bad or a priori good, but that is debatable. One of the dark sides of globalization, which is common in academic circles, is that it produces depersonalization. In other words, it greatly facilitates the process of identity disappearance, especially of those cultural forms that do not have great power and strength. In this way, values also disappear, particularly those related to human dignity. Economic globalization does so in a way that reduces all the rules to the laws of the market, and all the values to commercial and exchange values. A person is simply "terrorized" by the market, which colonizes the whole world. Everything that is ethical, spiritual, humane becomes marginal and neglected. This suggests that globalization alienates. It is important to emphasize that globalization also influences the mental, or the spiritual side of life. This happens through the media that consistently pump information into human consciousness and human subconsciousness, leading to disorientation of entire masses. Therefore, it becomes very interested in ethics, because every influence on consciousness, is also passive influence on conscience. In this way, Tićac very intelligently says the man has become "a moral surfer" who rapidly changes his preferred values. This is the argument that additionally affirms global ethics as a necessity, and therefore a model of ethics that primarily starts from the person, which is recognized as the highest value, is very relevant for this discussion. Raising a person to the highest level of ethical principles is the main demand of personalistic ethics and such a model appears as a response to the challenges of globalization. It additionally becomes more significant when we know that various personalism exists in the world. This means that a person is connected to truth, and that it is also worthy of love. "When we speak of the human person we are not just thinking of superiority, which involves a relation to other creatures, but we are thinking above all of what - or rather who - the human being essentially is. Who the human being essentially is derives primarily from within that being. All externalizationsactivity and creativity, works and products-have here their origin and their cause" (Wojtyla, 1980: 44). We have to admit that the ontological superiority of the human being is grounded in specific personal character of the human person. Since the person is the subject and goal of free mental activity, it must be treated as such. The integral vision of the man excludes utilitarianism as a principle of action, and we notice the thesis that globalisation requests certain desubjectification of the man, his self-negation, or request for "pluralisation". Theorists support these arguments with what is called violence against the person. Such violence is not classic violence, but violence over the truth and the value of the person. Just as one should not be treated as a material value, so too a person cannot be alienated. Here again we actualize the identity issue. Who does a man belongs to? While a small part exists for the sake of the whole, the man exists for himself and inside himself. He sees a purpose in himself. A person, thanks to his spiritual nature, exists inside himself in a unique and unrepeatable way. But this belonging to himself, does not mean shutting himself off. A person always believes there is another person, it is directed towards another. Exactly because it has himself, it opens up for other persons and makes relations with others. A person has the ability to participate in the humaneness of the other, by an act of goodness, solidarity and love. In post- 
modern society man has become something that is "replaceable" and this is what began the story on personalistic ethics. Individuals are irreplaceable as such, and everyone knows that no one can replace your father, mother, brother or friend. John F. Crosby wanted to point out the essential definition of the person, as well as the essential definition of autonomy. If a person owns himself, and belongs to himself, then it must be able to work out himself. "I may not want that which he wants me to want - and in this precisely I am incommunicabilis. I am, and I must be, independent in my actions. All human relationships are posited on this fact. All true conceptions about education and culture begin from and return to this point" (Wojtyla, 1979:238). This implies not only the antithesis of causal determination, but also other forms of violence. It testifies of today's society of consumerism, which aims turn both freedom of choice and autonomy into a commodity in the market. Modern man is capitulating to his own size. When we talk about the size, we are referring to a person as the holder of dignity. Ethical reflections would be sterile if they were to be satisfied with the statement that the other should be affirmed, instead of trying to show what is happening, what is it that's worth in the human being, and what should be preserved in all circumstances, without which the affirmation of the person would be impossible and illusory. Affirmation of a person for what he is inseparable from the truth, according to which a person is worthy of love, and deserves love. The basic norm of personalistic ethics has many formulations, but they all relate to the fundamental principle of love. Some critics say that love is important in personal, but not in social life, where the term "tolerance" is generally used more often. In response to this reasonable criticism and objections, we can briefly mention what R.Spiazzi wrote: "... characteristics of love are objectivity (because the love rises above the selfish interests and seeks objective good) and generosity (because the love encourages to do more than is one's duty, which results in various forms of cooperation, in short, a true triumph of good)" (Devčić, 1992:182). A similar case is with tolerance, which in any case should not be seen only as putting up with another person. This term also has to grow from the principle which says that the human person has fundamental human rights as well as inviolable dignity. Globalization and universality of the idea of human rights should be the instrument in establishing a responsible global policy based on ethics. The real pluralism that we seek would have to derive from the rights of those who are powerless and just because they are persons; because the inviolability of dignity guarantees such a universal principle. In this view, ethics is not doxa, but episteme. We have already pointed out that globalization, as it is now, did not advocate for a true universal community. Above all, this is confirmed by a huge gap between different social classes. The man as a being is ready to participate in any community, but his motive, above all, needs to be to participate in a fair community. Polish ethicist A. Szostek explains the concept of "neighbour" that is often used in ethics, and it came from theology. "What does it means to love one's neighbour as oneself? As oneself does not imply anything (the reason), but it refers to the solidarity we have inside as a measure of love that we need to give another person" (Wojtyla, 1979: 222). We can conclude from this that the foundation of the obligation for the affirmation of the other person is not self-love, but love for the people, love for the others. We said a lot about globalization: about the phenomena that accompany globalization, and all this has led to the conclusion that this process is evidently empty and hollow due to the recession of ethics that is evident. Jon Sobrino, one of the professors of theology in San Salvador, said that "globalization needs salvation". The cry seems to come primarily from the victims of globalization. "We have to ask the victims of our economic, financial and political structures what has the globalization brought to them? Did it truly make their world more humane or it has led to more poverty and misery? What are the hopes and goals that the poor want us to see?" (Sobrino, 2001:536). These questions present the answers that are primarily showing the poor and the victims not as objects, but as subjects of the global community. They too, just the same as the others, have the right to be asked about things in their lives. The victims of globalization have the potential and the power to change this process and to create a globalization the way it should be. Considering their contribution, Sobrino suggest three points of reflection: truth, solidarity and the civilisation of poverty. It is often said that globalization is just a very economical process. Therefore, the author 
rightly says that this is just a false image that determines man as homo oeconomicus. Such perceived globalization offers only one thing - the universality based on the principles of power and profiteering. "This is a model of unity that is centripetally (to the self as the centre) directed. We move toward authentic unity and universality of the human family when we are moving centrifugally and when we, at the same time, have the attitude that does not instrumentalise human relationships... once the suffering of victims is placed at the centre of 'globe', we reach the truth and universalisation. This has nothing to do with the mentality of the victims, but with the demanding call to respond to the victim in a humane way, with mercy and righteousness" (Ibid, :632). Sobrino does not stop here; he continues in the same rhythm urging greater global solidarity. Such solidarity can only be reached if we stand up for a person. This means not only providing material assistance to the victims, but a sustained engagement in assistance. In his opinion, the goal is not only to "to give something to others, but also receive something from the other." It is completely wrong to perceive "the victims" of globalization only as people who should be given something. On the contrary, they may be important factors in the overall rise of the entire civilization. "The civilization of poverty" that brings humanization of global proportions should be encouraged by all significant stakeholders. This kind of civilization would greatly help even those who fortunately do not fall into the aforementioned category. We have also mentioned the "moral surfers", a term that reflects our reality as a totalitarian relativism, or more precisely, as totalitarian materialistic pragmatism. The very metaphysics of a person, metaphysics of a man should be reason enough to look at it differently, and to act on it differently. A person should not be seen only as an object that aims to meet his own needs. Starting from the fact that a person, or a man is ready to give an adequate response to all goods, we conclude is that it is also capable of changing the course of globalization. All this speaks in favor of one of the main thesis, which is that even the responsible policy needs to come from the individual, from the person who is the holder of moral principles. If a person's ethics is simply recognized ethics as a model, this means that the change of global trends needs to be searched for in the microcosm, not in the "high places". Responsible global policy has quite the reverse approach compared to globalization as a political and economic process, because it starts from the individual, the one, the man, the person. Personalistic ethics is ethics of microcosm that aims to change the macrocosm. Its success is determined by many factors, but its failure is limited only by the will factor, which is lacking in order to have the whole process in the real perspective.

\section{CONCLUSION}

Finally, it should only be noted that it is important that reflections of the perspective of globalization and its ethicizing are becoming more and more prominent in the social sciences. Regardless of which model is the most acceptable, the first success is that we have a choice. Wherever you start from, it is expected that a positive development will be achieved, which is the basis of the story. Global community will become better and more functional only if it accepts its shortcomings, confronts them and determines the methods for their improvement. The same rule applies for the global society as for any other society - it is necessary to establish a system of values that will make the whole concept sustainable and acceptable for the majority of those affected by the process.

\section{REFERENCES:}

Bauman, Zygmunt (1998) Globalization, The Human Consequences, Columbia, University Press, New York

Beck, Urlich (2004) Moćprotiv moći u doba globalizacije, Školska knjiga, Zagreb

Boff, Leonardo (2000) Ethik, fur eine neue Welt, Patmos Verlag, Dusseldorf

Brink, D. (1989) Moral Realism and The Foundations of Ethics, Cambridge University Press, New York 
Abazović, D. (2016). Theories and models of globalization ethicizing. Journal of Human Sciences, 13(2), $2454-2461$. doi: $10.14687 /$ jhs.v13i2.3789

Devčić, Ivan (1992) Drustvena pravda, solidarnost i ljubav od enciklike, Bogoslovska smotra (3-4/1992), Zagreb

Dunning, John (2000) Wither Global Capitalism, Global Focus, vol. 12 nr.1, London

Faus, Jose Ignacio Gonzales (2001) Die Utopie der Menscheitsfamilie, Concilium Internationale Zeitschift fur theologie, 37 (5/2001), Mainz

Fioranza, Francis Shussler (2001) Pluralisum und Globalsierung: eineHerausforderung fur ethicheRefexion, Concilium, 37 (4/2001), Mainz

Frankfurt, Hary (2007) The Importance of What We Care about: Philosophical Essays, University press, Cambrige

Frankfurt, Hary (2007) The Importance of What We Care about: Philosophical Essays, University press, Cambrige

Freyer, Hans (1999) Theory Of Objective Mind: Introduction To The Philosophy Of Culture, University Press, Ohio

Gehlen, Arnold (2004) Moral und Hypermoral, Klostermann Vittorio, Bonn

Gould, Carol (2008) The New Global Ethics and its Three Faces, in An Ethics in an Era of Globalization edited by M.S. Ronald Commers, all at Ghent University, Belgium

Habermas, Jurgen (2002) Postmetafizičko mišjjenje: filozofski spisi, Beogradski krug, Beograd

Hesse, Helmut (1987) Wirtschaft und Moral, Bursfelder Universitätsrede, heft 6, Göttingen

Küng, Hans (2000) Global Responsibility, In Search of a New World Ethic,Crossroad, New York

Küng, Hans (2007) Svjetski etos za svjetsku politku, Intercon, Zagreb

Levinas, Emanuel (2006) Totalitet i beskonačnost, Službeni list SCG, Beograd

Lycan, W. G. (1986) Moral Facts and Moral Knowledge, u: The Southern Journal of Philosophy Vol. XXIV, Memphis State University, Memphis

Malnes R, Midgard.K (2009) Politicke filozofija, CID, Podgorica

Mervyn, Frost (2008), Global Ethics: anarchy, freedom and international relation, Taylor\&Fracis Library, New York

Pannenberg, Wolfhart (1985) Anthropology in Theological Perspective, T\&T Clark, London

Pogge and Horton (2008) Global Ethics: Seminal Essays St Paul MN, Paragon

Pogge, Thomas (2002) World Poverty and Human Rights, Polity press, Cambridge

Raiser, Konrad (2001) Weltordunung und Weltethos, Concilium 37 (4/2001), Mainz

Rich, Arthur (1994) Ethic of economy, Labor et fides, Geneve

Sobrino, Jon (2001) Der Erlosung der Globalisierung, Concilium 37 (5/2001) Internationale Zeitschrift für Theologie, Mainz

Tićac, Iris (2009) Personalistička etika kao odgovor na izazove globalizacije, Filozofska istraživanja 15, str 107-118, Zagreb

Wojtyla, Karol (1980) Von der Konigswurde des Menshen, Seewald Verlag, Stuttgard 